\title{
Comparative efficacy of chemical and botanical pesticides against citrus leaf minor (Phyllocnistis citrella Stainton)
}

\author{
SATISH B. MANE*, SASYA NAGAR AND SOBITA SIMON
}

Department of Entomology, Sam Higginbottom Institute of Agriculture, Technology and Sciences, ALLAHABAD (U.P.) INDIA

\section{ARITCLE INFO \\ Received : 23.06 .2016 \\ Revised : 28.08 .2016 \\ Accepted : 12.09 .2016}

\section{KEY WORDS :}

Dimethoate, Abamectin, Spinosad, Acetamiprid, Imidacloprid, Botanical pesticides

\begin{abstract}
The investigation was conducted with 8 Treatments:- Dimethoate 30 EC @ 0.03 per cent, Abamectin 1.8 EC @ 0.003 per cent, Spinosad 45 SC @ 0.03 per cent, Acetamiprid 20 SP @ 0.04 per cent, Imidacloprid 17.8 SL @ 0.005 per cent, Neem oil 2 per cent, NSKE 5 per cent and control (water spray) on citrus leaf minor. Such treatments were arranged in statistical design RBD with three replications. In overall, cumulative effect of 3 applications of all the treatments $\mathrm{T}_{5} \mathrm{Abamectin} 1.8 \mathrm{EC}(0.003 \%)$ recorded lowest $(7.66 \%)$ leaves infestation of leaf minor and found at par with $\mathrm{T}_{2}$ Spinosad $45 \mathrm{SC}(0.03 \%)$ i.e.8.42 per cent leaf infested. The next best effective treatments, $\mathrm{T}_{4}$ Acetamiprid $20 \mathrm{SP}(0.04 \%)$, $\mathrm{T}_{3}$ Imidacloprid $17.8 \mathrm{SL}(0.005 \%), \mathrm{T}_{1}$ Dimethoate 30 per cent $(0.03 \%), \mathrm{T}_{6}$ Neem oil (2\%) and $\mathrm{T}_{7} \operatorname{NSKE}(5 \%)$ with infestesion of 9.37 per cent, 10.46 per cent, 13.08 per cent, 14.63 per cent and 15.21 per cent, respectively and these treatments groups were at par with each other. Maximum infestation of leaf minor was noticed in control (water spray) is 24.75 per cent.
\end{abstract}

How to view point the article : Mane, Satish B., Nagar, Sasya and Simon, Sobita (2016). Comparative efficacy of chemical and botanical pesticides against citrus leaf minor (Phyllocnistis citrella Stainton). Internat. J. Plant Protec., 9(2) : 514-519, DOI : 10.15740/HAS/IJPP/9.2/514519. 